Tropical Journal of Pharmaceutical Research March 2017; 16 (3): 605-612

ISSN: 1596-5996 (print); 1596-9827 (electronic)

(C) Pharmacotherapy Group, Faculty of Pharmacy, University of Benin, Benin City, 300001 Nigeria.

All rights reserved.

Available online at http://www.tjpr.org

Original Research Article

http://dx.doi.org/10.4314/tjpr.v16i3.15

\title{
Anti-inflammatory and anti-apoptotic effect of Rhodiola crenulata extract on spinal cord injury in rats
}

\author{
Zhang Zhao-Bo, Teng Xiao and Jing- Zhang Sheng* \\ Department of Orthopedics, Taizhou Central Hospital, Taizhou 318000, China
}

${ }^{*}$ For correspondence: Email: zhangjingsheng1345@hotmail.com; Tel/Fax: 0086-576- 88526161

Received: 19 May 2016

Revised accepted: 4 February 2017

\begin{abstract}
Purpose: To investigate the effects of Rhodiola crenulata on injured spinal cord tissue recovery due to the presence of neuroprotective constituents such as salidroside, tyrosol, rosavins, and crenulatanoside.

Methods: Effect of R. crenulata extract (RCE) at doses of 10, 20 and $50 \mathrm{mg} \mathrm{kg}^{-1}$ was investigated for spinal cord injury (SCI) recovery in rat. The anti-inflammatory activity was estimated by haematoxylineosin (H\&E) staining and myeloperoxidase activity assay, while the anti-apoptotic effect was investigated by terminal deoxynucleotidyl transferase dUTP nick-end labelling (TUNEL) and caspase-3 activity assays in $\mathrm{SCl}$ tissue.

Results: RCE (10 mg mL $\left.{ }^{-1}\right)$ treatment resulted in a Basso, Beattie and Bresnahan (BBB) score of 14.50 \pm 1.22 , while negative control showed a BBB score of $6.17 \pm 1.60$. H\&E staining in test groups treated with 20 and $50 \mathrm{mg} \mathrm{kg}^{-1}$ RCE showed statistically different $(p<0.05)$ histological scores $(2.0 \pm 0.37$ and $1.83 \pm 0.31$, respectively) which are higher than those of SCl (S)-induced group. The estimates of apoptosis in SCl tissue) revealed significant differences from the normalised levels in RCE-treated groups.

Conclusion: The plant extract produced good recovery of injured spinal tissue, suggesting that further clinical trials and chemical constituent studies are warranted.
\end{abstract}

Keywords: Rhodiola crenulata, Haematoxylin-eosin, Caspase-3, Anti-inflammatory, Anti-apoptotic

Tropical Journal of Pharmaceutical Research is indexed by Science Citation Index (SciSearch), Scopus, International Pharmaceutical Abstract, Chemical Abstracts, Embase, Index Copernicus, EBSCO, African Index Medicus, JournalSeek, Journal Citation Reports/Science Edition, Directory of Open Access Journals (DOAJ), African Journal Online, Bioline International, Open-J-Gate and Pharmacy Abstracts

\section{INTRODUCTION}

Spinal cord injury (SCl) is a mechanical insult to the spinal canal, which results in primary changes in its morphology and physiology such as oedema, ischemia and haemorrhage. After $\mathrm{SCl}$ in the rat, typical necrosis along with apoptosis in white matter (WM) occurs in later phases, which is suggested to be the complete or partial cause of secondary degeneration at the injury site and chronic demyelination of tracts away from the injury [1,2]. Due to the presence of multiple stages and a complex pathogenesis in $\mathrm{SCl}$, therapeutics with multiple mechanisms are predicted to be most suited for the treatment of $\mathrm{SCl}$.

Recently, many studies in which medicinal plants (either in part or extract form) have shown their effectiveness in the treatment of spinal cord- or central nervous system-related injuries. One such medicinal plant, Rhodiola crenulata, has been reported to be effective as a nervous system stimulant [3], anti-depressant [4], enhancer of exercise performance and exertion reducer [5], altitude sickness-preventing agent [6], and antiapoptotic agent [7]. It is also known to inhibit $\alpha$-amylase, $\alpha$-glucosidase and 
angiotensin I converting enzyme (ACE), hence it is an anti-diabetic and antihypertensive agent [8] and is a standard phytotherapy in many Asian countries. Reported phytochemical constituents of this medicinal plant mainly include salidroside, tyrosol, rosavins, crenulatanoside A,

4'-hydroxyacetophenone, epicatechin- $(4 \beta, 8)$ epicatechin gallate, phenylpropanoid compounds and lignans. Among its many constituents, salidroside has been studied widely and evaluated for its antioxidant, anti-apoptotic $[9,10]$, anti-inflammatory [9], antibacterial [11], and neuroprotective properties [12].

Due to the presence of effective neuroprotective constituents, the extract of this plant has been selected for treating spinal cord injury. After performing an extensive literature review, we found no studies that reported the use of $R$. crenulata extract (RCE) for the treatment of $\mathrm{SCl}$.

\section{EXPERIMENTAL}

\section{Plant material}

Leaves and flowers of $R$. crenulata used in this study were collected from Guangzhou Baoxing Biotechnologies, China and identified by a taxonomist, Professor Ding-Xian Han, College of Life Science \& Technology, Huazhong University of Science \& Technology, China. Plant material was dried for 7 days in the shade. Dried leaves and flowers were ground with an electrical grinder, passed through sieve number $5(4 \mathrm{~mm}$ diameter), and used for extraction purposes.

\section{Preparation of extract}

An alcohol extract was prepared as described, with several modifications depending upon the requirements and available facilities [13]. Dried powder of leaves and flowers of $R$. crenulata $(100 \mathrm{~g})$ was placed in a soxhlet extraction unit, and hot extraction was carried out at $60^{\circ} \mathrm{C}$ with $500 \mathrm{~mL}$ ethanol for $15 \mathrm{~h}$. The extract was filtered using a vacuum filter (Millipore, filter pore size $0.45 \mu \mathrm{m}$ ) to obtain soluble compounds only. To concentrate the extract $(500 \mathrm{~mL})$, a rotary evaporator was used to concentrate the solution $(\sim 50 \mathrm{~mL})$ and was dried by lyophilisation.

\section{Animal care, $\mathrm{SCl}$ development, and experimental design}

Male Sprague-Dawley adult rats $(180-250 \mathrm{~g})$ were used for in vivo experiments. The experimental procedures followed the Declaration of the National Institutes of Health Guide for Care and Use of Laboratory Animals. The animals were housed under standard laboratory conditions at $25{ }^{\circ} \mathrm{C}$, with $12 \mathrm{~h} / 12 \mathrm{~h}$ light/dark exposure, and free access to water and food. An adaptation period of 2 weeks was given to the animals at the experimental facility before commencement of experiments. The experimental procedures were in compliance with the Guide for Care and Use of Laboratory Animals [14].

The protocol for induction of $\mathrm{SCl}$ by the weightdrop technique was performed as described with few modifications $[1,15]$ and was approved by the Institutional Committee for Experimental Animal Care, Department of Orthopaedics, Taizhou Central Hospital (ref no. 2015431800). Before carrying out the surgical operation, all instruments were sterilised by autoclaving. In addition, rats were given anaesthesia with ketamine-xylazine (at doses of 20 and $75 \mathrm{mg} \mathrm{kg}^{-}$ $\left.{ }^{1}\right)$ injections by the intraperitoneal route before carrying out the surgery. Laminectomy was performed at spinal T9-T11 to expose the spinal cord, and injury was induced by dropping a 10-g weight from a height of $12.5 \mathrm{~cm}$.

The sham/control (L) group animals were subjected to laminectomy only. Sterile saline solution $(0.09 \% \mathrm{NaCl})$ was given as vehicle control. In the sham-treatment group/treatment control (LT), laminectomised animals (not $\mathrm{SCl}$ ) were treated with the highest concentration of extract used in the study. RCE at $50 \mathrm{mg} \mathrm{kg}^{-1}$ was given $1 \mathrm{~h}$ before surgery. The $\mathrm{SCl}$-induced group/negative control group (S) was subjected to weight drop exposure at the laminectomised T11 position of the spinal cord and injected with vehicle control. RCE was given at three concentrations $\left(10,20\right.$ and $\left.50 \mathrm{mg} \mathrm{kg}^{-1}\right)$ to three groups of animals (STI, STII and STIII, respectively) $1 \mathrm{~h}$ before induction of spinal injury. The fresh injury in rats was immediately filled with an intrathecal reagent infusion using an osmotic pump (Model 2002, Alzet, Cupertino, CA, USA) implanted subcutaneously and was removed before suture-closing of the wound. Each animal was given penicillin injection $\left(200,000 \mathrm{U} \mathrm{rat}^{-1}\right.$ day $^{-1}$, intramuscularly) for 4 days to prevent infection. Post-surgical pain was ameliorated with buprenorphine injection $(0.03$ $\mathrm{mg} \mathrm{kg}^{-1}$ ) for 3 days. Animals were given free access to food and water after surgery. As per the requirements of the specific investigations regarding behavioural studies, anti-inflammatory activity, antiapoptotic activity or tissue staining, the rats were sacrificed using cervical dislocation. The damaged tissue from the T9-T11 region was excised from the whole spinal cord, and T1-T12 and was taken for specific investigation. 


\section{Behavioural studies}

After injuring the spinal cord, recovery of motor function was checked in each group (6 animals in each group) on subsequent days (days $0,5,10$, $15,20,25$ and 30) twice a day. Animals with spinal injury were scored according to the 21 criteria of Basso, Beattie and Bresnahan (BBB) [16]. Three investigators, blinded to treatment, evaluated and scored the behaviour of the animals.

\section{Haematoxylin-eosin (H\&E) staining}

The animals in each group $(n=3)$ were sacrificed $24 \mathrm{~h}$ after injury and subjected to icecold $4 \%$ paraformaldehyde. The spinal cord was collected and fixed. Spinal cord sections from control- and RCE-treated animals were stained as a set to compare identically processed tissue. The slices were observed under a microscope by blinded investigators who scored the samples on a scale of 0-4 for oedema, where 0 indicates no or minor levels of neutrophil infiltration and haemorrhage; 1 indicates modest or limited, 2 indicates intermediate, 3 indicates widespread or prominent, and 4 indicates widespread and highly prominent levels $[1,17]$.

\section{Myeloperoxidase (MPO) activity assay}

MPO activity is an indirect indication of neutrophil infiltration. The weighed and homogenised spinal cord tissues from rats in all groups $(n=3)$ at $24 \mathrm{~h}$ after SCl were assessed for MPO activity. Homogenisation was carried out in potassium phosphate buffer $(\mathrm{pH} 7,10 \mathrm{mM})$ containing hexadecyltrimethyl-ammonium bromide 0.5 $\%(w / v)$. Centrifugation was carried out at 10,000 $\times g$ for $20 \mathrm{~min}$ at $4{ }^{\circ} \mathrm{C}$. Supernatant volume equivalents containing $10-\mu \mathrm{g}$ protein were mixed with $2.0 \mathrm{mM}$ tetramethylbenzidine and $0.05 \mathrm{mM}$ $\mathrm{H}_{2} \mathrm{O}_{2}$. Absorbance changes were observed at $425 \mathrm{~nm}$. The unit of enzyme-specific activity was defined as the amount of enzyme required to catalyse $1 \mu \mathrm{mol}$ of $\mathrm{H}_{2} \mathrm{O}_{2}$ per min per $\mathrm{mg}$ of protein at $37^{\circ} \mathrm{C}$ and was represented as $\mathrm{MPOg}^{-1}$ wet tissue $[1,18]$.

\section{Apoptotic assay}

DNA degradation by endonuclease is a key indicator of cell death (apoptosis and necrosis) resulting in double-stranded DNA fragments (oligonucleotides). Terminal deoxynucleotidyl transferase (TdT) dUTP nick-end labelling (TUNEL) is an appropriate assay for DNA fragmentation (apoptotic/necrotic) in situ. The tissue was taken from all groups $(n=3)$ on day 2 after $\mathrm{SCl}$. Tissue slices were adhered to the slide, washed with phosphate buffer ( $\mathrm{pH} 7.0,50$ $\mathrm{mM}$ ) and digested with proteinase $\mathrm{K}$ (incubation for $30 \mathrm{~min}$ at $37^{\circ} \mathrm{C}$ ) to permeabilise the cells. After washing with PBS, the slides were dipped in the reagents (TdT and dUTP) of Apoptag plus peroxidase in situ kit (Chemicon, Temecula, CA) and incubated for $1 \mathrm{~h}$ at $37^{\circ} \mathrm{C}$ according to the kit protocols. Counterstaining was performed to detect the non-apoptotic cells using methyl green. For control, TdT enzyme was excluded from the incubation. The number of TUNELpositive cells was counted with $\mathrm{a} \times 20$ objective in 20 sections of grey matter (GM) (i.e., neurons) and WM (i.e. oligodendrocytes) at 5 days after $\mathrm{SCl}$, and the average number of TUNEL-positive cells per 200 cells was reported. TUNEL-positive cells showed a clear nuclear condensation along with clear demarcation between GM and WM $[1,18]$.

A caspase-3 assay kit (Calbiochem, San Diego, CA) was used for determining the caspase 3 activity according to the manufacturer's instructions. The enzyme acts on the labelled substrate Ac-Asp-Glu-Val-Asp-pNA (DEVD-pNA) and produces $p$-nitroanilide $(p N A)$, which is analysed to quantify enzyme activity. Homogenised injured spinal cord tissue samples were lysed by treatment with iced lysis buffer (10 mM HEPES, $\mathrm{pH} 7.4 ; 2$ mM ethylenediaminetetraacetic acid; $0.1 \%$ 3-[(3-cholamidopropyl) dimethylammonio]-1-propanesulfonate; $5 \mathrm{mM}$ dithiothreitol; $1 \mathrm{mM}$ phenylmethylsulfonylfluoride; $10 \mu \mathrm{g} \mathrm{m}^{-1}$ pepstatin-A; $10 \mu \mathrm{g} \mathrm{mL}^{-1}$ aprotinin; 20 $\mu \mathrm{g} \mathrm{mL} \mathrm{L}^{-1}$ leupeptin) for $10 \mathrm{~min}$; $30 \mu \mathrm{L}$ of tissue samples and $30 \mu \mathrm{L}$ assay buffer containing 10 $\mathrm{mM}$ DTT, $5 \mathrm{mM}$ DEVD-pNA (substrate) in phosphate buffer $(\mathrm{pH} 7,5 \mathrm{mM})$ were added to wells, and the microplate was equilibrated at 37 ${ }^{\circ} \mathrm{C}$ for $10 \mathrm{~min}$. Absorbance at $405 \mathrm{~nm}$ was determined with an ELISA micro-plate reader (Emax, Molecular Devices) at $405 \mathrm{~nm}[19,20]$.

\section{Statistical analysis}

Statistical analysis was performed with GraphPad Prism and based on an analysis of variance (ANOVA). A significant difference was established with respect to the control group when $p<0.05$.

\section{RESULTS}

RCE showed a yield of $3.45 \pm 1.5 \%(\mathrm{w} / \mathrm{w})$ of dried plant used). The concentration of a key component (i.e., salidroside) in RCE was determined by HPLC as described [21], which was found to be $11.32 \pm 2.21 \mathrm{mg} \mathrm{g}^{-1}$ dry weight of extract. 
All animals showed an open field locomotion score of 21 on the BBB scale prior to injury ( $L$ and LT groups, as shown in Figure 1). Even with the lowest concentration of RCE $\left(10 \mathrm{mg} \mathrm{mL}^{-1}\right)$, a significant increase $(p<0.5)$ in motor recovery was observed, with a BBB score of $14.50 \pm 1.22$ compared to the S group's BBB score of $6.17 \pm$ 1.60 at the end of study (i.e. 30 days). Higher concentrations of RCE (20 and $50 \mathrm{mg} \mathrm{mL}^{-1}$ ) showed significantly higher effects $(14.50 \pm 1.37$ and $15.83 \pm 1.60$, respectively, on the BBB scale) than the lower $\left(10 \mathrm{mg} \mathrm{mL}^{-1}\right)$ concentration of RCE (BBB score of $6.17 \pm 1.60$; Figure 1).
H\&E staining showed histological changes (Figure 2A) in $\mathrm{SCl}$ rats, including an influx of leukocytes (granulocytes) at the injured tissue, and cell numbers increased with the severity of injury [22].

The $\mathrm{L}$ and $\mathrm{LT}$ groups showed very low histological scores of $0.17 \pm 0.17$ (mean \pm SEM) and $0.33 \pm 0.21$, while the SCl-induced group/negative control group (S) displayed a maximum score of $3.8 \pm 0.17$. The STI, STII and

巴L
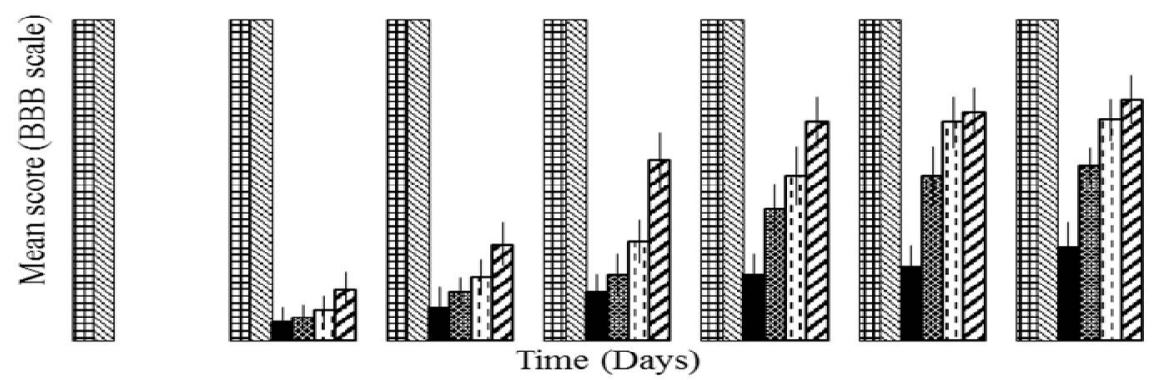

Figure 1: Open field walking behaviour representing motor recovery with time using the Basso, Beattie and Bresnahan (BBB) scale

A

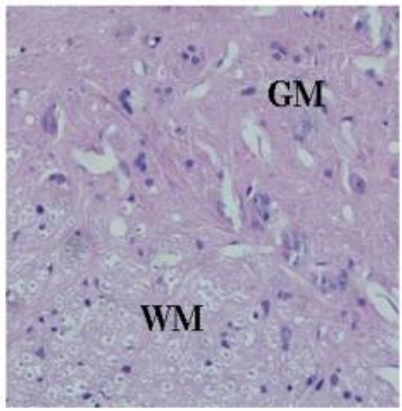

L

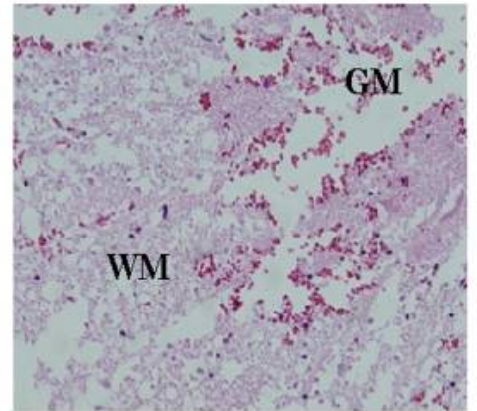

S

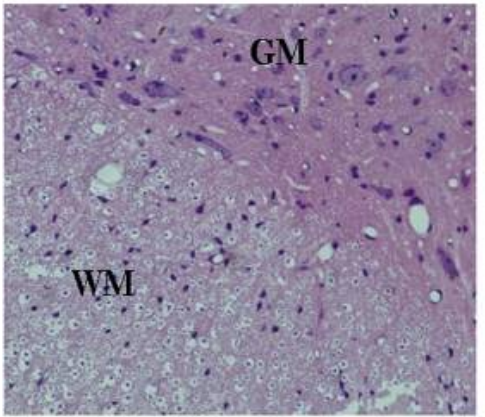

STIII

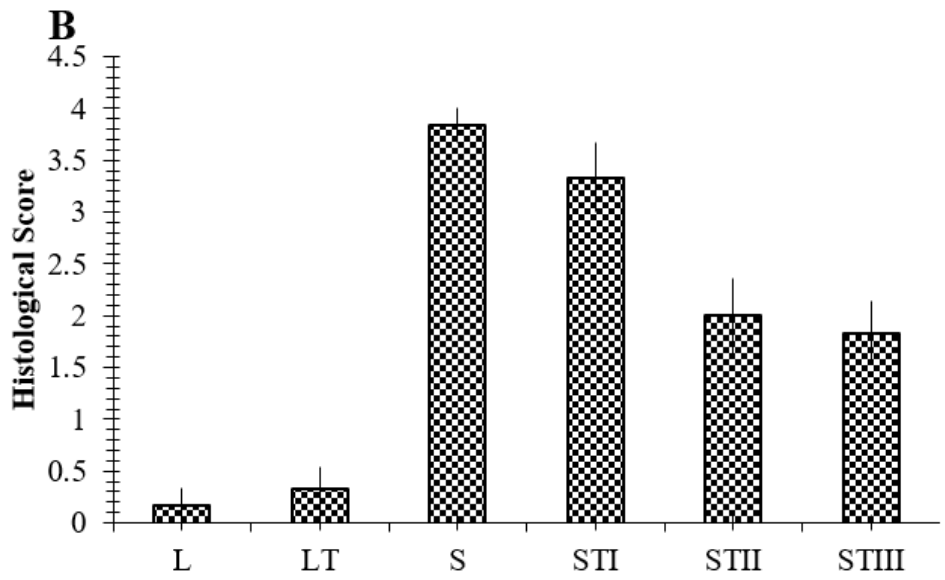

Figure 2: Representative images of haematoxylin-eosin (H\&E)-stained spinal cord tissue $(A)$. WM, white matter, GM, grey matter (B) 
STIII test groups that received 10, 20 and $50 \mathrm{mg}$ $\mathrm{kg}^{-1}$ RCE showed histological scores of $3.33 \pm$ $0.33,2.0 \pm 0.37$, and $1.83 \pm 0.31$, respectively. STII and STIII groups showed scores that differed significantly $(p<0.05)$ from those of the $\mathrm{SCl}$ (S)-induced group, with the histology appearing almost normal (Figure 2B).

The differences in MPO activity (mean \pm SEM) between the $L$ and LT groups (5.34 \pm 0.46 and $5.02 \pm 1.43 \mu \mathrm{mol} \mathrm{min} \mathrm{mg}^{-1}$ ) were statistically

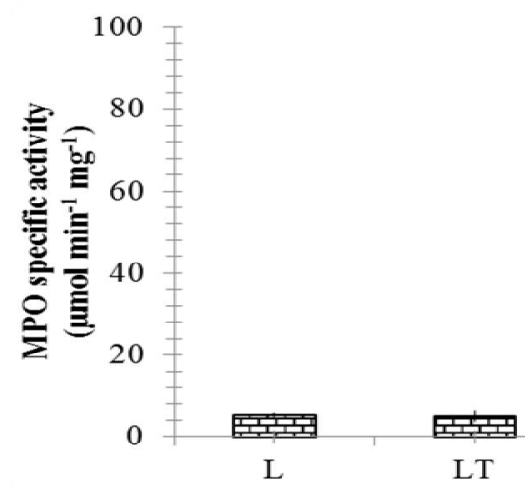

insignificant $(p>0.05)$; however, there was a significant increase in MPO activity $(p<0.05)$ in the SCl-induced S group $(87.25 \pm 3.55)$ due to the infiltration of leukocytes at the inflammatory/injury regions ( Figure 3 ).

The TUNEL method recognises the blunt ends of DNA fragments using the enzyme TdTase by attaching labelled dUTPs to the 3'-hydroxyl termini of DNA ends, which can be visualised (Figure 4A).

Figure 3: Effect of Rhodiola crenulata extract on MPO-specific activity in SCI wet tissue

\section{A}

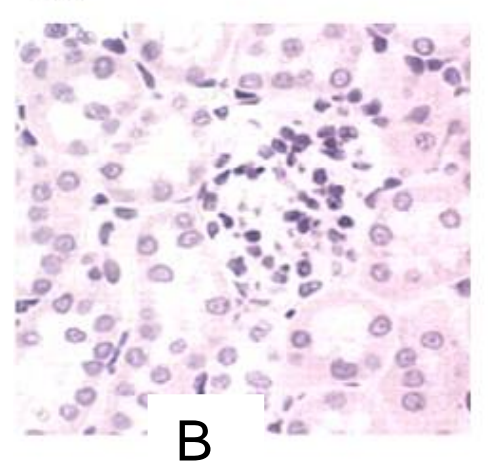

L

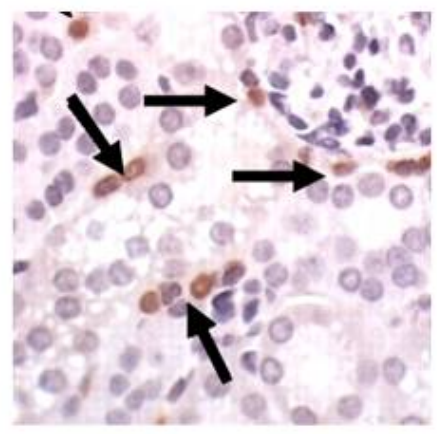

S

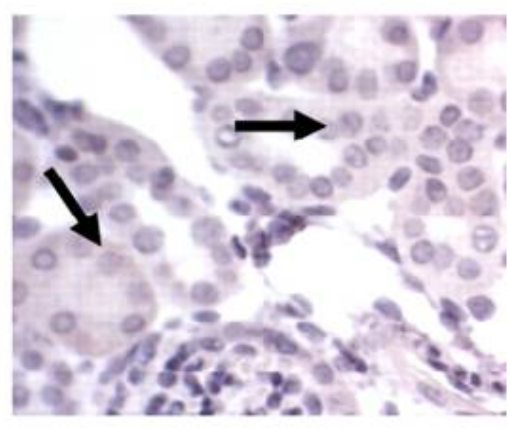

STIII

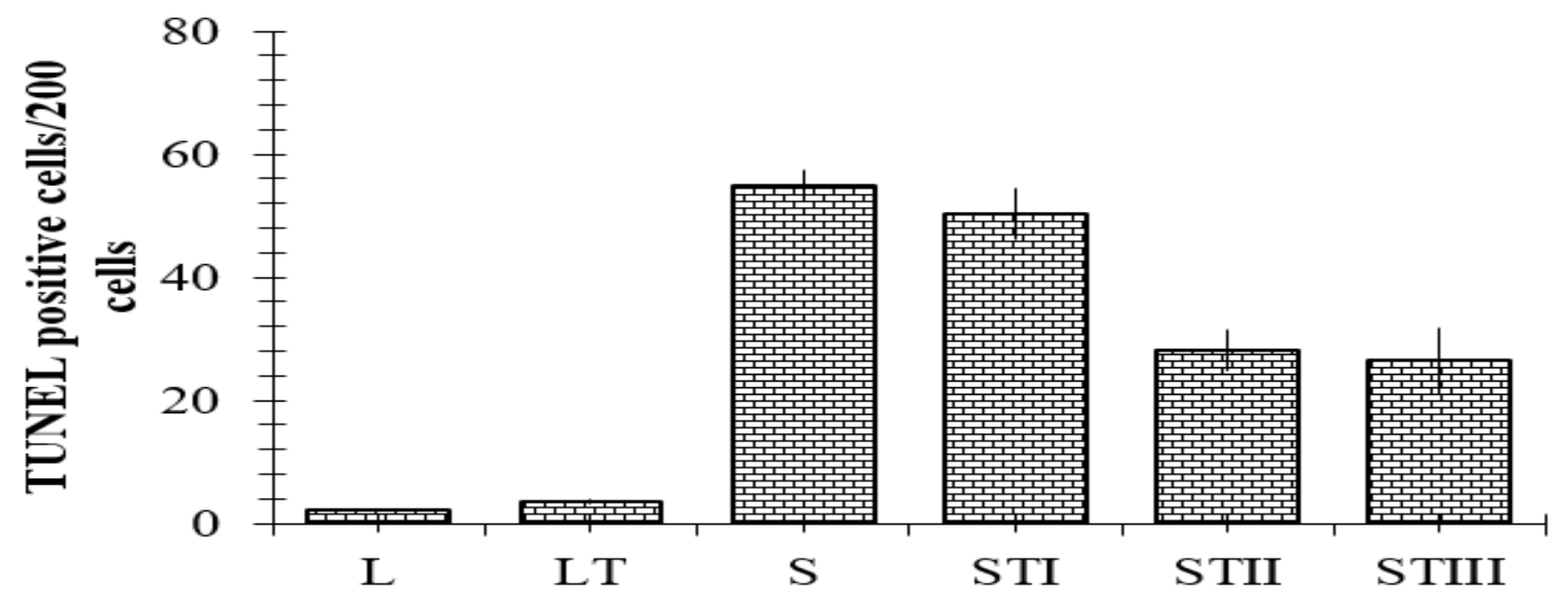

Figure 4: Effect of RCE on apoptotic cell death of neurons shown by representative images $(A)$ and quantitative analysis (B) 


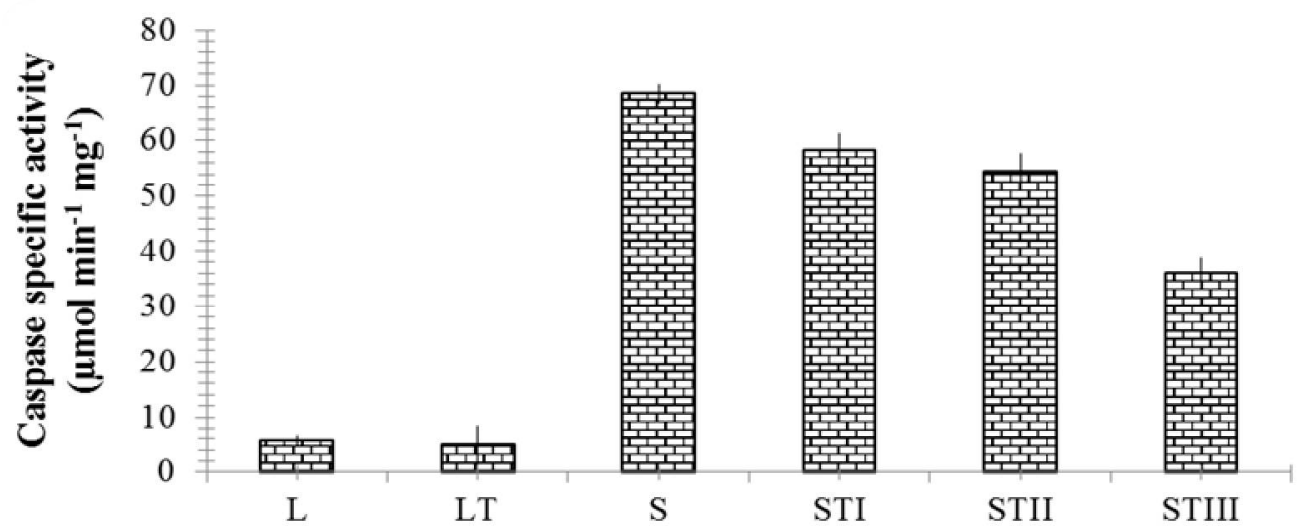

Figure 5: Effect of RCE on caspase 3 activity

The $L$ and $L T$ groups showed the lowest average number $(2.12 \pm 0.153$ and $3.53 \pm 0.342$, respectively) of TUNEL-stained cells per 200 cells observed, which were statistically similar ( $p$ $>0.05$ ). S tissue showed high TUNEL staining ( $54.99 \pm 2.34$ cells per 200 cells) while the RCEtreated STII and STIII groups (20 and $50 \mathrm{mg} \mathrm{kg}$ $\left.{ }^{1}\right)$ showed statistically lower numbers $(p<0.05)$ of TUNEL-stained cells $(28.17 \pm 3.44$ and 26.42 \pm 5.32 per 200 cells) (Figure 4 B).

As expected, the pattern of the caspase 3 assay (Figure 5) was also similar to the TUNEL staining study but only STIII (50 mg kg$\left.{ }^{-1}\right)$ demonstrated a significant effect $(p<0.05)$ compared to the negative control $S$ group $\left(36.17 \pm 2.55 \mu \mathrm{mol} \mathrm{min}^{-1}\right.$ ${ }^{1} \mathrm{mg}^{-1}$ versus $68.51 \pm 1.64 \mu \mathrm{mol} \mathrm{min}{ }^{-1} \mathrm{mg}^{-1}$ ).

\section{DISCUSSION}

The present study investigated the use of ethanolic extract of $R$. crenulata in $\mathrm{SCl}$ in rats by performing behavioural, histological, and molecular studies. The extract of this plant has already shown its potential in cognitive diseases, like Alzheimer's disease, in a streptozocineinduced animal model [23]. It also has neurogenerative properties specific to the hippocampal region of the brain [13]. Its main constituent, salidroside, has good antioxidant properties [21,24], which contribute to its antiapoptotic, antinecrotic, and neuroprotective activities.

From Figure 1, various interpretations can be formed and discussed in detail. Notably, even the STI group, which was treated with the lowest concentration of RCE $\left(10 \mathrm{mg} \mathrm{mL}^{-1}\right)$, showed a significant increase $(p<0.5)$ in motor recovery, demonstrating a better BBB score compared to that of the $S$ group at the end of the study (30 days). Furthermore, the higher concentrations of RCE (20 and $50 \mathrm{mg} \mathrm{mL}^{-1}$ ) showed significantly higher effects on the BBB scale than the lower concentration of RCE $\left(10 \mathrm{mg} \mathrm{mL}^{-1}\right)$. In a previous study, tissue at the lesion centre was related to behavioural functional recovery, as demonstrated by the BBB score. A score of 8/9 represented the plateau in recovery for all groups at 3 weeks post injury, which was a significant change over time $(p<0.0001)$, while differences were insignificant among the three groups $(p=0.196)$ [25].

In another study, an implant containing polymer scaffold seeded with neural stem cells was used for treating spinal cord injury and was studied for sub-chronic (28 days) or chronic phase (70 days) recovery. With $\mathrm{SCl}$, both hindlimbs were affected and the scaffold-neural stem cell-treated group showed stabilisation, with a BBB score of 12 and plantar stepping with frequent to consistent weight bearing and occasional forelimb-hindlimb coordination [16] on and after 56 days postinjury. The control group and cell-alone group achieved stabilisation, showing 6 and 7 on the BBB scale, respectively, whereas the scaffoldalone group showed stabilisation, with a BBB score of 9 which was higher than controls [26].

H\&E staining showed histological changes, such as an influx of leukocytes (granulocytes) to the injured tissue and cell numbers increasing with the severity of injury. H\&E staining has been used widely due to its compatibility with a wide range of fixatives, recognising a broad range of tissue types and changes in their morphology. Haematoxylin shows specific affinity to nucleic acid materials, giving a deep blue/purple colour, whereas eosin stains almost all proteins in a pink colour of different intensities. In the MPO assay, less MPO activity in the treatment group represents a low level of inflammation [1].

Programmed cell death, apoptosis, is a normal physiological process in various situations like homeostasis. Ladder-patterned DNA fragments of 180-200 bp on agarose gel electrophoresis cannot provide information regarding the 
apoptotic or localised DNA fragmentation. DNA damage is not specific to apoptosis only but occurs in necrosis as well; therefore, other specific studies were also required such as apoptosis-induced protease caspase 3 to support the above observation [27].

\section{CONCLUSION}

Salidroside-containing extract of $R$. crenulata exerts positive effects in animals after spinal cord injury. Furthermore, RCE-treated animals show behavioural recovery and anti-inflammatory and anti-apoptotic activities. Therefore, this plant warrants further studies including the isolation, identification and characterisation of the chemical constituents responsible for the observed activities.

\section{DECLARATIONS}

\section{Acknowledgement}

The authors acknowledge the administration of Taizhou Central Hospital, China for providing funds and facilities for the research.

\section{Conflict of Interest}

No conflict of interest associated with this work.

\section{Contribution of Authors}

The authors declare that this work was done by the authors named in this article and all liabilities pertaining to claims relating to the content of this article will be borne by them.

\section{Open Access}

This is an Open Access article that uses a funding model which does not charge readers or their institutions for access and distributed under the terms of the Creative Commons Attribution License (http://creativecommons.org/licenses/by 14.0) and the Budapest Open Access Initiative (http://www.budapestopenaccessinitiative.org/rea d), which permit unrestricted use, distribution, and reproduction in any medium, provided the original work is properly credited.

\section{REFERENCES}

1. Yin $X$, Yin $Y$, Cao F-L, Chen $Y-F$, Peng $Y$, Hou W-G, Sun $S-K$, Luo Z-J. Tanshinone IIA attenuates the inflammatory response and apoptosis after traumatic injury of the spinal cord in adult rats. PLOS ONE 2012; 7: e38381.
2. Crowe MJ, Bresnahan JC, Shuman SL, Masters JN, Crowe MS. Apoptosis and delayed degeneration after spinal cord injury in rats and monkeys. Nat Med 1997; 3: 73-76.

3. Gerbarg PL, Illig PA, Brown RP. Rhodiola rosea 10 in Psychiatric and Medical Practice. in: Rhodiola rosea. ed., 2014, p. 225.

4. Mao JJ, Xie SX, Zee J, Soeller I, Li QS, Rockwell K, Amsterdam JD. Rhodiola rosea versus sertraline for major depressive disorder: A randomized placebocontrolled trial. Phytomed 2015; 22: 394-399.

5. Noreen EE, Buckley JG, Lewis SL, Brandauer J, Stuempfle KJ. The effects of an acute dose of Rhodiola rosea on endurance exercise performance. J Streng Cond Res 2013; 27: 839-847.

6. Abidov M, Crendal F, Grachev S, Seifulla R, Ziegenfuss $T$. Effect of extracts from Rhodiola rosea and Rhodiola crenulata (Crassulaceae) roots on ATP content in mitochondria of skeletal muscles. Bull Exp Biol Med 2003; 136: 585-587.

7. Liu $M-W$, Su $M-X$, Zhang $W$, Zhang $L-M$, Wang $Y-H$, Qian $C$-Y. Rhodiola rosea suppresses thymus T-lymphocyte apoptosis by downregulating tumor necrosis factor-ainduced protein 8-like-2 in septic rats. Int $\mathrm{J} \mathrm{Mol} \mathrm{Med}$ 2015; 36: 386-398.

8. Kwon Y-I, Hae-Dong J, Shetty K. Evaluation of Rhodiola crenulata and Rhodiola rosea for management of type II diabetes and hypertension. Asia Pac J Clin Nutr 2006; 15: 425.

9. Liu S, Yu X, Hu B, Zou Y, Li J, Bo L, Deng X. Salidroside rescued mice from experimental sepsis through antiinflammatory and anti-apoptosis effects. J Surg Res 2015; 195: 277-283.

10. Qian EW, Ge DT, Kong S-K. Salidroside protects human erythrocytes against hydrogen peroxide-induced apoptosis. J Nat Prod 2012; 75: 531-537.

11. Coenye T, Brackman G, Rigole P, De Witte E, Honraet $K$, Rossel B, Nelis HJ. Eradication of Propionibacterium acnes biofilms by plant extracts and putative identification of icariin, resveratrol and salidroside as active compounds. Phytomed 2012; 19: 409-412.

12. Shi T-y, Feng S-f, Xing J-h, Wu Y-m, Li X-q, Zhang N, Tian Z, Liu S-b, Zhao M-g. Neuroprotective effects of Salidroside and its analogue tyrosol galactoside against focal cerebral ischemia in vivo and H2O2-induced neurotoxicity in vitro. Neurotox Res 2012; 21: 358-367.

13. Qu Z-q, Zhou Y, Zeng Y-s, Lin Y-k, Li Y, Zhong Z-q, Chan WY. Protective effects of a Rhodiola crenulata extract and salidroside on hippocampal neurogenesis against streptozotocin-induced neural injury in the rat. PLoS ONE 2012; 7: e29641.

14. Qu WS, Tian DS, Guo ZB, Fang J, Zhang Q, Yu ZY, Xie MJ, Zhang $H Q$, Lu JG, Wang W. Inhibition of EGFR/MAPK signaling reduces microglial inflammatory response and the associated secondary damage in rats after spinal cord injury. J Neuroinflammation 2012; 9: 2094-2099. 
15. Basso DM, Beattie MS, Bresnahan JC, Anderson DK, Faden Al, Gruner JA, Holford TR, Hsu CY, Noble LJ, Nockels R. MASCIS evaluation of open field locomotor scores: effects of experience and teamwork on reliability. J Neurotrauma 1996; 13: 343-359.

16. Montalto A, Bitto A, Irrera $N$, Polito $F$, Rinaldi $M$, Antonuccio $P$, Impellizzeri $P$, Altavilla $D$, Squadrito $F$, Romeo C. CO2 pneumoperitoneum impact on early liver and lung cytokine expression in a rat model of abdominal sepsis. Surg Endosc 2012; 26: 984-989.

17. Esposito E, Bruscoli S, Mazzon E, Paterniti I, Coppo M, Velardi E, Cuzzocrea S, Riccardi C. Glucocorticoidinduced leucine zipper (GILZ) over-expression in $T$ lymphocytes inhibits inflammation and tissue damage in spinal cord injury. Neurotherapeutics 2012; 9: 210-225.

18. Ersahin M, Cevik O, Akakin D, Sener A, Ozbay L, Yegen $B C$, Sener G. Montelukast inhibits caspase-3 activity and ameliorates oxidative damage in the spinal cord and urinary bladder of rats with spinal cord injury. Prostaglandins Other Lipid Mediat 2012; 99: 131-139.

19. Ramasamy S, Wahab NA, Abidin NZ, Manickam S. Effect of extracts from Phyllanthus watsonii Airy Shaw on cell apoptosis in cultured human breast cancer MCF-7 cells. Exp Toxicol Pathol 2013; 65: 341-349.

20. Sandner B, Ciatipis M, Motsch M, Soljanik I, Weidner N, Blesch A. Limited functional effects of subacute syngeneic bone marrow stromal cell transplantation after rat spinal cord contusion injury. Cell Transplant 2016; 25: 125-139.

21. Campolo M, Esposito E, Ahmad A, Di Paola R, Wallace JL, Cuzzocrea S. A hydrogen sulfide-releasing cyclooxygenase inhibitor markedly accelerates recovery from experimental spinal cord injury. The FASEB Journal 2013; 27: 4489-4499.

22. Teng YD, Lavik EB, Qu X, Park Kl, Ourednik J, Zurakowski $D$, Langer $R$, Snyder EY. Functional recovery following traumatic spinal cord injury mediated by a unique polymer scaffold seeded with neural stem cells. Proc Nat Aca Sci 2002; 99: 3024-3029.

23. Kyrylkova $K$, Kyryachenko $S$, Leid M, Kioussi $C$. Detection of apoptosis by TUNEL assay. in: C. Kioussi, C. Kioussis. Odontogenesis "Methods and Protocols". 1st ed. New York: Springer, 2012; pp 41-47. 